\title{
How to increase the value of bilateral trade? Currency union versus fixed exchange rate regime
}

\author{
Oleksandra Ivanievna Stoykova
}

\begin{abstract}
A B S T R A C T
Objective: The objective of the article is to determine which exchange rate regime provides higher bilateral trade: fixed rate or currency union.

Research Design \& Methods: An index was designed based on variables commonly recognised as those that might affect the value of bilateral trade and those that are differently affected by fixed exchange rate regime and currency union. These variables are trade openness, trading partner trade importance, similarities of government debt and borrowing, similarities of inflation, and the correlation coefficient of detrended GDP. The index serves as a dependent variable in the main model, which was created using principal component analysis. I also ran models with both trade openness and trading partner trade importance as dependent variables. Findings: Although the index appeared to be higher in countries with a currency union, the results show that a currency union does not provide higher values of bilateral trade compared to a fixed exchange rate regime. Implications \& Recommendations: Research can be repeated with more attention dedicated to independent variables. Alternative de facto classifications of exchange rate regimes can be used for future studies as well.

Contribution \& Value Added: The article contributes to existing studies on exchange rate regimes that commonly and interchangeably use notions of fixed exchange rate regime and currency union. To my best knowledge, there is no previous empirical research that would separately compare the impact on trade of these notions. The current study fills this gap.

Article type: research article

Keywords:

fixed exchange rate; currency union; trade integration; Optimum Currency Area; ex-

JEL codes: change rate regimes F15, F33, F36, F45

Received: 19 February 2020 Revised: 15 October 2020 Accepted: 24 November 2020
\end{abstract}

Suggested citation:

Stoykova, O.I. (2021). How to increase the value of bilateral trade? Currency union versus fixed exchange rate regime. Entrepreneurial Business and Economics Review, 9(2), 21-38. https://doi.org/10.15678/EBER.2021.090202

\section{INTRODUCTION}

A currency union $(\mathrm{CU})$ is one of the highest levels of economic integration. Without a doubt, a common currency has great advantages for the countries that adopt it. However, the example of the Eurozone illustrates that it can also cause significant problems. The main reason for such problems - and hence the major drawback of a currency union - is the inability to use exchange rate mechanisms as a tool of economic adjustment. A CU is hard to create in the first place, and then it is even harder to dissolve. In fact, it is almost impossible, or at least no such mechanism has been developed so far. On the other hand, politics play a significant role during the creation of a $\mathrm{CU}$, and in some cases, it may prove to become an unavoidable obstacle. Finally, the cost of creating a CU can be prohibitive.

All of the above makes economists think about alternatives that can bring similar economic benefits but at the same time avoid such dramatic consequences. Although Rose and Engel (2002) or Bakucs, Benedek, and Ferto (2019) showed that countries within currency unions are more integrated than countries that have separate currencies, it still makes sense to consider a fixed exchange rate 
regime $^{1}$ as a suitable candidate for a currency union alternative. There are several studies indicating that "hard peg" increases trade volume among countries by reducing exchange rate risk and transaction costs (Klein \& Shambaugh, 2004).

There also exist several articles that discuss the differences between fixed exchange rate regimes and the Optimum Currency Area's (OCA) ability to promote macroeconomic indicators (De Grauwe, 2012; McCallum, 1995; Mendizabal, 2002). These scholars do not examine the issue directly but mention the difference of both regimes' characteristics concerning their ability to affect economic variables (Kinnunen, Androniceanu, \& Georgescu, 2019). In fact, the two notions are commonly used synonymously. Already in 1961, Mundell stated that a currency area is a domain within which exchange rates are fixed. Engel and Rose (2002, p. 1) argue that "the large size of this 'border effect' is mostly the result of exchange rate volatility or, more generally, the consequence of having different national moneys." In this case, different currencies are used as a synonym for volatile exchange rates. However, low nominal exchange rate volatility is also a characteristic of a fixed exchange rate regime. Thus, we may suggest that the difference in the ability of pegs and common currency to promote macroeconomic indicators may be much lower than a consequent disadvantage of a CU as opposed to a fixed exchange regime. If this is a fact, many countries would choose the latter.

The main goal of this study is to investigate whether a common currency area can bring more economic benefits measured by the value of bilateral trade compared to a fixed exchange rate regime based on two groups of countries. The countries are chosen in such a way that one group within the sample comprises countries within a currency union - for which the exchange rate is fixed to a certain foreign currency - and the second group of countries uses a fixed exchange rate with the same currency as the CU. For instance, currency union $A$ is fixed to country C's currency, while the group of countries $B$ has fixed exchange rate regimes with the same country C's currency. The value of bilateral trade and the indicators that might affect it in the long run within a currency union are compared to the same between $A$ and $B$ so as to confirm the research hypothesis that a CU brings more economic benefits than a fixed exchange rate regime (for more, see Appendix A).

The article is divided into three parts. Firstly, a theoretical section reviews the differences between a fixed exchange rate and a currency union in general, but it also overviews the ability of both to promote trade values. The second part presents the methods employed in the study and describes the relevant data. It starts with an explanation of the sample choice and later discusses data and data sources, along with the index creation procedure. The next part shows the results obtained during the research, which is followed by conclusion.

\section{LITERATURE REVIEW}

\section{The optimum currency area theory}

Trade has played a crucial role in the emergence of developing economies (Gryczka, 2020; Loganathan et al., 2020; Martyniuk \& Murawska, 2021; Maciejewski \& Wach, 2019). To address the main goal of the paper, we should discuss the costs and benefits of both regimes. As for the currency union, the framework used for analysis of its pros and cons is known as the optimum currency area (OCA) theory. According to its definition, a currency area is considered optimal if the benefits of having a single currency exceed its costs. In other words, the OCA is a region in which having single currency is the most efficient exchange rate regime.

Mundell (1961), father of the OCA theory, implicitly defines the OCA as a region in which the cost of losing the ability to conduct independent monetary policy is lower than the benefits from a single currency. Hence why he believed that countries should form a currency union if they do not suffer from asymmetric shocks. For situations when this is not the case, Mundell develops several criteria for the currency area to be considered optimal. Those are high labour mobility, price, and wage flexibility.

\footnotetext{
${ }^{1}$ It seems appropriate to mention that for the purposes of this paper the term "fixed exchange rate regime" indicates both "hard" and "soft" pegs, as defined by the International Monetary Fund (IMF, 2004) classification. However, if the difference is crucial or the terms "hard" and "soft" pegs were used in a cited article, the author may use those terms as well.
} 
His findings are supported by modern investigations on labour mobility and regional factors of wages differentiation (Kostiukevych, Mishchuk, Zhidebekkyzy, Nakonieczny, \& Akimov, 2020; Mishchuk, Samoliuk, Bilan, \& Streimikiene, 2018).

The second best-known author in the OCA theory is McKinnon (1963), who complements Mundell's theory by dividing factors mobility among regions and industries. McKinnon believes that high labour mobility among industries can offset the importance of the mobility between regions. McKinnon agrees with the importance of Mundell's high capital and labour mobility but additionally stresses the importance of high openness to trade and the small size of the economy as criteria for an OCA.

However, Kenen (1969) indicates that perfect labour mobility does not exist. According to him, high product diversification is a more suitable criterion. Although, this is contradicts McKinnon's conclusion about trade openness because - as highlighted by Kenen - diversified economies are likely to have a relatively small marginal propensity to import.

In turn, Corden (1973) questions Mundell's suggestion that long run adjustment can be done with the help of labour mobility. However, he fully agrees with Mundell's suggestion that price and wage flexibility are the most essential criteria. Furthermore, Fleming (1971) and Magnifico (1971) highlight the importance of inflation similarities for successful monetary unification. In 1973, Mundell changed his mind about flexible exchange rate as an effective tool to stabilise the economy in case of asymmetric shocks. Instead, he then considered flexible exchange rate as a source of asymmetric shocks. In other words, he emphasised that one of the main (or even: the main) negative consequences of currency union no longer results in significant losses.

This view by Mundell is the first appearance in the OCA literature of what later will be named by Frankel and Rose (1998) as the endogeneity hypothesis of the optimum currency area criteria. This hypothesis implies that some criteria - mentioned as important for a successful currency union - can be satisfied not prior to a currency union formation but after countries peg their currencies. Researchers mention such sources of endogeneity as trade, labour market flexibility, institutions, financial integration, the synchronisation of shocks, and output (Frankel \& Rose, 1998; Melitz, 2004; Baele et al. 2004, Ferto, 2018; Moździerz, 2019; Androniceanu, Kinnunen, \& Georgescu, 2020). Among other institutional factors of endogeneity, positive changes in government expenditure and money supply are one of the main (Sriyana, 2019; Androniceanu, 2020). However, the endogeneity of mentioned indicators is not always the case. The OCA criteria may not have endogenous properties or even lead to opposite result. One of the examples of such a situation is Krugman's specialisation effect, which is mostly discussed within the new OCA theory, developed after the creation of the Eurozone. The new OCA theory again raised the issue of the loss of ability to conduct an independent monetary policy as a huge cost for member states (Alesina et al., 2002, Melitz, 1991). Moreover, the new OCA theory highlights several other preconditions for the OCA, such as real convergence (Dellas \& Tavlas, 2009), business cycle synchronisation (BCS) and its determinants (Frankel \& Rose, 1998; Skare \& PoradaRochoń, 2019a), and the similarity of labour market institutions (De Grauwe, 2012).

Most of the aforementioned drawbacks apply to the case of fixed exchange rate. As I already mentioned, some of the discussed articles introduce the same notions interchangeably. The next subchapter focuses on the comparison of drawbacks of both regimes.

\section{Currency union vs fixed exchange rate regime}

The main difference between a currency union and a fixed exchange rate regime is that currency unions have one central bank for the whole area; hence, they share exchange rate and monetary policy. However, this results in one of the biggest disadvantages of the currency union: the impossibility to use the exchange rate mechanism for short-run adjustments among member states. According to the discussed OCA theory, such an action requires certain preconditions, such as similar inflation and gross domestic product (GDP) growth rates, high labour mobility, and a stable exchange rate for certain period. Hence why the use of a common currency requires a two-sided agreement. On the other hand, the adoption of a fixed exchange rate is a one-sided decision. Generally, a country can choose any other country to peg to despite their economic similarities, and the former can devalue its national currency rather easily if necessary, as I discussed above. At the same time, these 
countries still benefit from certain privileges of the currency union, such as the promotion of international trade due to the lack of exchange rate uncertainty.

Nevertheless, the property of a fixed exchange rate regime to devaluate currency if needed is also its disadvantage. There is no $100 \%$ certainty that the peg will hold, which may also affect longrun expectations. A good example is the history of the exchange rate in Ukraine. During the 18-yearslong period of a fixed exchange rate regime, the Ukrainian hryvna was devalued almost six times (Gorodnichenko, 2015).

Reinhart and Rogoff (2004) mention that - in most cases - their statistical approach fails to confirm exchange rate regimes de jure. Pegs are easier to abolish with the help of black market or dual exchange rates. If black or dual markets exist, such a country would have a higher deviation of the exchange rate on average. However, the possibility of the existence of a black market for national currency in the case of a currency union is very limited.

\section{Difference between currency union and fixed exchange rate regimes in terms of their ability to promote bilateral trade}

The literature in the field indicates that there are several macroeconomic variables that might be differently affected by fixed an exchange rate regime and a CU. This subchapter focuses on such indicators. Eventually, these indicators will be cross-checked with determinants of bilateral trade. If such an indicator appears to be on the list of the latter, it will be included in the index that will serve as a dependent variable in the econometric model. Obviously, the index will include proxies for bilateral trade itself.

Noteworthy, the leading indicator that is differently affected by discussed exchange rate regimes is bilateral trade. Frankel and Rose (1998) or Smutka, Svatoš, Tomšík, and Sergienko (2016) argue that trade indicators are endogenous. The positive influence of a $\mathrm{CU}$ on trade is also mentioned by Mundell (1961), Glick and Rose (2002), Rose and Engel (2002), and Beck (2017). The empirical results of these studies mostly vary from a $40 \%$ to $100 \%$ increase in bilateral trade in the case of the adoption of a single currency. However, there also exists an alternative view. Persson (2001) criticises the overestimating of the role of a CU membership. He claims that the fact that $\mathrm{CU}$ members are systematically different from non-members is likely to distort such results.

Moreover, there are several studies that emphasise the negative correlation between transaction costs and the volume of bilateral trade (De Grauwe, 2012; McCallum, 1995). Mendizabal (2002) indicates that the reduction of transaction costs is much lower - even though still present - in the case of fixed exchange rates compared to monetary union. However, one should account for trade volumes in a specific currency union. If intra-regional trade in an area is considerably small (service-oriented economies), the effect of the transaction cost reduction will not be noticeable. Hargreaves and McDermott (1999) evaluate the benefits of transaction costs in New Zealand in the case of a possible currency union with Australia so as to conclude that it would be rather small $(-0.13 \%)$. The result for a New Zealand-USA union is estimated to be higher due to the widespread use of the USD. Since the value of transaction cost is different for a fixed exchange rate regime and a $\mathrm{CU}$, the proxies for trade integration among countries should be developed into a dependent variable in this research (Malefane, 2021).

One of the differences between a fixed exchange rate regime and a $\mathrm{CU}$ is that the former can allow for a fluctuation of exchange rate, while the credibility of a stable rate is higher in the case of the latter. However, scholars have different opinions on the relationship between the variability of exchange rate and bilateral trade volumes. Among others, Klein and Shambaugh (2006), Tenreyro (2007), and Thursby and Thursby (1987) confirm the hypothesis that exchange rate risk negatively influences trade values. Alternatively, the Krugman specialisation effect shows that countries with zero or very low variability of the exchange rate can be more integrated even with a lower volume of international transactions. Furthermore, Dautovic et al. (2014) estimate that the effect of the strictness of exchange rate and intra-industry trade is negative. Broda and Romalis (2013) state that the relationship between trade and an exchange rate regime may be caused by reverse causality. This is not the case in CU with hard pegs because of a predefined exchange rate; however, this assumption questions previous findings on the relationship between exchange rate and trade. Nicita (2013) argues that exchange rate 
volatility may not affect trade badly because of sunk costs and the availability of other financial instruments for countries with flexible exchange rate arrangements. All of the above only confirms the reason behind the inclusion of bilateral trade indicators into the independent variable.

Moreover, an increase in trade volume causes a rise in other macroeconomic indicators. For instance, BCS tends to increase with the rise in bilateral trade (Beck \& Janus, 2013, 2014; Frankel \& Rose, 1998). The opposite situation - known as the Krugman specialisation effect (Krugman, 1993) - shows that countries that experience an increase in trade are more likely to specialise in production. This leads to different productivity shocks and lowers business cycle correlation. Furthermore, BCS is sensitive to fluctuations of the exchange rate (Beck, 2019). Since BCS is a precondition in the OCA theory, states that consider joining a $\mathrm{CU}$ or fixing their exchange rate would definitely aim for higher values of the indicator. Noteworthy, bilateral trade and a number of other variables discussed in this research are considered as determinants of BCS; i.e. exchange rate fluctuation, transaction costs, membership in a $\mathrm{CU}$, and financial integration. It is interesting that BCS - endogenous in the OCA theory mainly due to the influence of trade values - is itself a determinant of bilateral trade values (Inklaar et al., 2008)

Financial integration is another benefit possibly obtained from the adoption of a CU (Skare \& Porada-Rochoń, 2019b). Pagano (2004) concludes that both primary and secondary bond markets integrated significantly after the Eurozone creation. Lane (2006) mentions that the government bond spread dropped. Although this dynamics changed after the 2008 financial crisis, Afonso et al. (2015) estimate that it was mainly associated with a negative post-crisis growth. Therefore, the pure effect of a CU is puzzling. The relationship between financial integration and BCS is also ambiguous. Backus et al. (1992) and Imbs $(2004,2006)$ indicate negative correlation, while Kose et. al. (2012) and Monnet and Puy (2016) stress positive correlation. Given the relationship between BCS, trade, and financial integration, we may say that an indirect link exists between the latter two elements. This relationship emerges from Ricardian's and Heckscher-Ohlin's theoretical models (Kletzer \& Bardhan, 1987), and it was confirmed by empirical studies (Beck, 2003). Hence why this indicator will be included in the index.

Noteworthy, most of the above studies were performed for European countries, and there is evidence indicating that the OCA theory and its endogeneity phenomenon in particular should be applied with caution for less developed countries (Stoykova, 2018; Adams, 2005).

\section{RESEARCH METHODOLOGY}

This section will present empirical research seeking to confirm the study's hypothesis: a currency union provides higher bilateral trade values for member countries compared to a fixed exchange rate regime. This section starts with an explanation of the sample choice, followed by a description of data and methodology. Results of estimations required for hypothesis testing appear at the end of the section.

\section{Sample choice}

To perform the analysis, we need two groups of countries: countries in a currency union - with their currency pegged to another foreign currency - and countries with fixed exchange rate regimes with the same currency as the first group. Moreover, these two groups of countries should have similar regional, economic, and cultural characteristics. This is needed so as to ensure that trade integration occurs due to a difference in the observed variable (currency union dummy). To ensure a relatively large sample, I worked on countries pegged either to the USD or the EUR since these are the most common pegs (Table 1).

As for countries pegged to the euro, there is a clear choice. Both the WAEMU and the CAEMC countries - the latter sharing a common border - should be included in the analysis. Among currently existing unions, these two groups have the highest economic and social similarities. European countries pegged to the EUR (i.e. Bulgaria, Bosnia and Herzegovina, and Denmark) could possibly serve as a third group in this sample. However, cultural similarity in these countries is not as high as in case of currency unions. Moreover, three countries would form a small sample that would differ greatly with both currency unions. As for dollarised countries, one should choose the one most similar to countries of the ECCU in terms of the abovementioned criteria. Given their geographical location, it is reasonable to take other Caribbean or Central American countries for this purpose. These are The Bahamas, Aruba, 
Barbados, Belize, Curacao, Panama, Venezuela, and St Martin. Unfortunately, the analysis of existing databases gives no desired data for Anguilla, Curacao, and St Martin.

Table 1. Countries pegged to the EUR and the USD

\begin{tabular}{|c|l|l|}
\hline $\begin{array}{c}\text { Currency union } \\
\text { membership }\end{array}$ & \multicolumn{1}{|c|}{ Countries pegged to the EUR } & \multicolumn{1}{c|}{ Countries pegged to the USD } \\
\hline \multirow{5}{*}{ Yes } & $\begin{array}{l}\text { Central African EConomic and Monetary } \\
\text { Community (CAEMC): Cameroon, Central } \\
\text { African Republic, Chad, Gabon, Equatorial } \\
\text { Guinea, Republic of Congo } \\
\text { West African Economic and Monetary Un- } \\
\text { ion (WAEMU): Benin, Burkina Faso, Guinea- } \\
\text { Bissau, Mali, Niger, Senegal, Togo }\end{array}$ & $\begin{array}{l}\text { Eastern Caribbean Currency Union (ECCU): } \\
\text { Anguilla, Antigua and Barbuda, Dominica, } \\
\text { Grenada, Saint Kitts and Nevis, Saint Lucia, } \\
\text { Saint Vincent and The Grenadines }\end{array}$ \\
\hline No & $\begin{array}{l}\text { Bulgaria, Bosnia and Herzegovina, Cabo } \\
\text { Verde, Comoros, Cote d'Ivoire, Denmark, } \\
\text { Sao Tome and Principe }\end{array}$ & $\begin{array}{l}\text { Aruba, The Bahamas, Bahrain, Barbados, } \\
\text { Belize, Bermuda, Curacao, Djibouti, Eritrea, } \\
\text { Hong Kong, Jordan, Oman, Panama, Qatar, } \\
\text { Saudi Arabia, Sint Maarten, South Sudan, } \\
\text { Turkmenistan, United Arabian Emirates, } \\
\text { Venezuela }\end{array}$ \\
\hline
\end{tabular}

Source: own elaboration based on the International Monetary Fund (IMF) "De Facto Classification of Exchange Rate Regimes and Monetary Policy Framework," 2004.

The final list of analysed countries is as follows:

- WAEMU: Benin, Burkina Faso, Guinea-Bissau, Mali, Niger, Senegal, Togo;

- CAEMC Central African Republic, Cameroon, Chad, Gabon, the Republic of Congo, Equatorial Guinea;

- ECCU: Antigua and Barbuda, Grenada, Dominica, Saint Kitts and Nevis, Saint Vincent and The Grenadines, Saint Lucia;

- Central American and Caribbean countries: The Bahamas, Aruba, Barbados, Belize, Panama, Venezuela.

Index

Initially, bilateral data for 210 country pairs were collected. However, some of these pairs were dropped due to the lack of some entries. In the end, the sample was reduced to 160 cross-section observations. The aim adopted during the construction of the sample was to keep balance between the number of variables and the number of observations so as to obtain the highest possible combination of both. Crosssectional data for 2017 was used, which was the last year with good-quality data available.

The dependent variable in the model was chosen to be the index that will capture all macroeconomic variables that are differently affected by the regimes under scrutiny and, at the same time, that are determinants and proxies of bilateral trade.

Bilateral trade openness and trading partner trade importance are used as a proxy for trade integration. Variables are measured using the formulas below. Data for trade is taken from the IMF Direction of Trade Statistics Dataset. Data for GDP comes from the World Bank Development Indicators Database (2000).

where:

$$
\text { Trade_openness }(i, j)=\frac{X_{i j}+M_{i j}}{Y_{i}}
$$

$X_{i j}$ - is bilateral exports between country i and country $j$;

$M_{i j}$ - is bilateral imports between country i and country $j$;

$Y_{i}$ - is real GDP of country $i$.

where:

$$
\text { Trade_importance }(i, j)=\frac{X_{i j}+M_{i j}}{X_{i}+M_{i}}
$$

$M_{i}$ - is total imports of country $i$

$X_{i}$ - is total exports of country $i$. 
The inflation rate will be used as a first proxy for financial integration. This variable is represented by CPI-based inflation $\left(I N F L A T I O N_{i j}\right)$. Another indicator is government net borrowing $\left(B_{0 R R O W I N G}\right)$, measured using the procedure described in König and Ohr (2013). Pairwise correlation for the preceding five-year period is considered for the construction of two previously mentioned variables. Finally, the similarity in government debt is also a variable $\left(D E B T_{i j}\right)$, calculated as the difference in government debt of country $i$ and an average value for the indicator within the analysed group; i.e. the African group and the American group. Perfect integration in the case of government debt is achieved when the difference equals zero. All data in this section is provided by the World Bank Development Indicators Database (2000).

Furthermore, I added a proxy for asymmetric movement of output, which is designed as a pairwise correlation coefficient of detrended GDP (Beck, 2013; 2017). Detrended GDP was obtained using the Hodrick-Prescott filter with lambda equal to 6.25, as proposed by Ravn and Uhlig (2002):

$$
G D P_{i j}=\operatorname{cor}\left(y_{i}, y_{j}\right)=\frac{\operatorname{cov}\left(y_{i}, y_{j}\right)}{\sqrt{\operatorname{var}\left(y_{i}\right) \times \operatorname{var}\left(y_{j}\right)}}
$$

in which, $y_{i}, y_{j}$ are cyclical components of real GDPs for five preceding years in USD for countries $i$ and $\mathrm{j}$, respectively. The low value of the coefficient indicates divergent business cycles.

Finally, the index assumes the following form:

$$
\begin{aligned}
& \text { INDEX }_{i j}=a \cdot \text { TRADEIMPORTANCE }_{i j}+b \cdot \text { TRADEOPENNESS }_{i j}+c \cdot \text { GDP }_{i j}+ \\
& d \cdot \text { INFLATION }_{i j}+e \cdot \text { DEBT }_{i j}+f \cdot \text { BORROWING }_{i j}
\end{aligned}
$$

in which, $a, b, c, d, e$, and $f$ are corresponding weighting rates defined by principal component analysis (PCA).

\section{Normalisation procedure}

Because the constructed variables have different scales of measurement, the application of proper normalisation is required. This study employs a methodology similar to the one presented by König and $\mathrm{Ohr}$ (2013), in whose work all variables obtain values from zero to one, except for correlation coefficients.

We don't need to normalise trading partner trade importance because it takes a value from zero to one by definition. As for trade openness, the normalised values take the form of

where:

$$
\text { Trade openness }(i, j)=\left(\frac{\text { Value }_{i j}-\text { Minvalue }_{i}}{\text { MaxValue }_{i}-\text { Minvalue }_{i}}\right)
$$

Value $_{i j}$ - is the value of bilateral trade openness for country i with country $j$;

Minvalue $_{j}$ - is the minimum value of bilateral trade openness for country $i$;

Maxvalue $_{j}$ - is the maximum value of bilateral trade openness for country $i$.

However, correlation coefficients for GDP, inflation, and government net borrowing can assume values from minus one to one. Negative values indicate disintegration and are allowed for the index.

The ratio of public debt is transformed in the following way:

where:

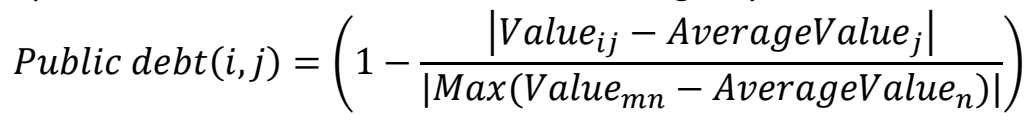

Value $_{i j}-$ AverageValue $_{j}$ - AverageValue ${ }_{j}$ is the public debt difference between the value of country $i$ and the average value for the group; and

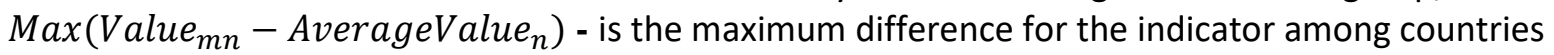
in the analysed group.

The weighing procedure was done using Principal Component Analysis For more, see Appendix B. Appendix C shows the index's results. 


\section{Independent variables}

Apart from the variable of main interest - the currency union dummy - I decided to include additional gravity variables such as the logarithm of physical distance between countries and a categorical variable that measures the similarity in culture as a sum of several dummy variables: a dummy for common language, common borders, common colony, and a dummy indicating whether the countries were historically part of one country. All the data were taken from Centre d'Études Prospectives et d'Informations Internationales (CEPII) gravity dataset. The main reason for the inclusion of these variables was to separate other than currency union effects on dependent variable. Such an approach is commonly used to test the CU effect on trade (Rose, 2001). Because the index heavily relies on trade, the inclusion of gravity variables to the model is more than justified.

\section{RESULTS AND DISCUSSION}

This section describes the empirical results using the approaches discussed in the previous section.

\section{Models}

The estimations were performed using the ordinary least squares method improved with the Newey-West estimator because all of them exhibit autocorrelation, heteroscedasticity, or both. In addition to the main model, which illustrates the influence of the currency union dummy and other independent variables on the index, I decided to run regressions with both trade openness and trading partner trade importance as regressands.

\section{Africa}

The signs of all but one insignificant coefficient in the model with dependent variable "index" depicted in Table 2 coincide with the theoretical assumptions. The currency union dummy is significant at the $1 \%$ level and has a positive sign. Based on this model and given the same level of physical distance and cultural similarities, countries within MU have on average a 13\% higher index than countries with fixed rates. As for the coefficient of determination, we may consider it high, especially in comparison to two other models. Significant at the $5 \%$ level, physical distance shows the expected result, which is consistent with gravity models. However, the categorical variable which summarises cultural, geographic, and historical similarities appears to be insignificant. A visual inspection of this variable indicates a very homogeneous characteristic of these countries, regardless of whether they belong to a single MU. About $85 \%$ of the sample has the highest or second-highest result for this variable. It is possible that dividing this regressor into four different variables may solve this issue.

A similar result appears in the next two models. However, the coefficient of determination is relatively low. In these models, $80 \%$ of the variation in the model is explained by other independent variables.

The effect of $\mathrm{CU}$ is extremely low. This might indicate that the members of a CU will benefit from higher trade values in the long run since it takes time for trade's determinants to affect it. However, that would only be true if the links between index components other than trade and bilateral trade are such as discussed in the literature. Moreover, as I already mentioned, the OCA theory and its endogeneity view are less applicable in the case of non-European countries. Furthermore, quite unexpectedly, coefficients of distance are lower than in the previous case.

\section{America}

A similar yet different outcome appeared for South and Central American countries. The significance of the proxy for similarity in all three cases supports the idea that its lack for African countries was due to geographical and historical homogeneity. The relative appearance of coefficients in the three preceding models is similar to the African case. Significant at the $1 \%$ level, physical distance has the second highest coefficient in the first model. In contrast, trade openness strongly relies on physical distance between partners in African countries. The most interesting observation is that the $\mathrm{CU}$ has a negative significant effect in all models. Such a result can be explained by the fact that the analysed countries 
Table 2. Estimation results for African countries ${ }^{2}$

\begin{tabular}{|l|l|l|l|}
\hline \multicolumn{1}{|c|}{ Dependent Variable } & \multicolumn{1}{c|}{ Index } & Trading Partner Trade Importance & \multicolumn{1}{c|}{ Trade Openness } \\
\hline Independent variables & $\mathrm{X}$ & $\mathrm{X}$ & $\mathrm{X}$ \\
\hline Constant term & $0.37079^{* * *}$ & $0.04681^{*}$ & $0.64521^{*}$ \\
\hline Log of physical distance & $-0.04525^{* *}$ & $-0.00701^{*}$ & $-0.09294^{*}$ \\
\hline Currency union dummy & $0.13391^{* * *}$ & $0.00755^{* * *}$ & $0.08530^{* * *}$ \\
\hline Categorical variable "similarities" & -0.00168 & 0.00249 & 0.02351 \\
\hline R-squared & 0.52448 & 0.25769 & 0.23910 \\
\hline Adj. R-squared & 0.50494 & 0.22719 & 0.20784 \\
\hline
\end{tabular}

$* * *$ significance at the $1 \%$ level, $* *$ significance at the $5 \%$ level, $*$ significance at the $10 \%$ level

Source: own elaboration based on the IMF Direction of Trade Statistics (DOTS), CEPII Gravity, prepared in Eviews 8.

mostly specialise in tourism, and the amount of international trade among them - the main component of the index - is lower than in the case of African countries. As I discussed in the theoretical part, bilateral trade values serve as a link between a currency union and all other components of the index. Moreover, the proportion of bilateral trade in American countries is only a small portion of its total trade. Given the latter and the relatively low R-squared, we may say that the relationship between a $\mathrm{CU}$ dummy and dependent variables might be just a correlation.

In the African countries, the amount of bilateral trade is significantly higher for those members of a $\mathrm{CU}$ that are landlocked. This suggests that the ability of a currency union to promote trade values is highly connected with geographical characteristics, such as common borders. The American sample comprises island nations, which significantly increases the cost of transportation between these countries.

The negative influence of currency union on trade also appears in the case of the Krugman specialisation effect. Due to the increase in trade, countries are more likely to specialise in production. Therefore, their income correlation decreases, while it is one of the index's components. However, this does not explain the phenomenon of the negative $\mathrm{CU}$ dummy coefficient for regression with two other dependent variables. Such a result also provides more evidence that the OCA theory might not apply to countries that are not members of the Eurozone.

Table 3. Estimation results for American countries ${ }^{3}$

\begin{tabular}{|l|l|l|l|}
\hline \multicolumn{1}{|c|}{ Dependent Variable } & \multicolumn{1}{c|}{ Index } & Trading Partner Trade Importance & \multicolumn{1}{c|}{ Trade openness } \\
\hline Independent variables & $\mathrm{X}$ & $\mathrm{X}$ & $\mathrm{X}$ \\
\hline Constant term & $0.71380^{* * *}$ & $0.05547^{* * *}$ & $1.33418^{* * *}$ \\
\hline Log of physical distance & $-0.08893^{* * *}$ & $-0.00702^{* * *}$ & $-0.17056^{* * *}$ \\
\hline Currency union dummy & $-0.14715^{* * *}$ & $-0.01225^{* * *}$ & $-0.28199^{* * *}$ \\
\hline Categorical variable "similarities" & $0.01672^{* *}$ & $0.00116^{*}$ & $0.03276^{* *}$ \\
\hline R-squared & 0.31059 & 0.32208 & 0.31059 \\
\hline Adj. R-squared & 0.28373 & 0.29567 & 0.28373 \\
\hline
\end{tabular}

*** significance at the $1 \%$ level, ${ }^{* *}$ significance at the $5 \%$ level, ${ }^{*}$ significance at the $10 \%$ level

Source: own elaboration based on the IMF DOTS, CEPII Gravity, prepared in Eviews 8.

Given a sufficiently low coefficient in both cases, we may conclude that common currency does not have a considerable influence on bilateral trade values compared to fixed exchange rates.

Nevertheless, we should consider that the results differ across the analysed regions. Moreover, the coefficients for the currency union dummy are almost the same in absolute terms but appear to have opposite signs. We may say that the answer to the main hypothesis of the study is highly path dependent. Unfortunately, this finding cannot be confirmed by a different sample because such a sample does not exist. However, several studies indicate such a notion while analysing a neighbouring topic, the determinants of OCAs (Adams, 2005; Stoykova, 2018).

\footnotetext{
2 The implementation of the "general to specific" strategy and the introduction of a quantile regression model do not provide quantitatively different results. For the results, see Appendix $E$ and $D$, respectively.

${ }^{3}$ The introduction of a quantile regression model does not provide quantitatively different results. For the results, see appendix D.
} 


\section{CONCLUSIONS}

This study was to test the hypothesis of currency union as a more favourable exchange regime than a fixed exchange rate regime for states that desire to promote bilateral trade. The study includes a literature review in order to find the indicators that are possibly affected differently by two extreme exchange rate regimes - the fixed exchange rate and the currency union - while simultaneously being determinants of bilateral trade. Unfortunately, the existing literature does not provide for an extensive overview of this topic. The research is complicated by the fact that the "fixed exchange rate regime" and the "currency union" are commonly used interchangeably. Nevertheless, the differences in the impact of both exchange rate regimes found in the literature and discussed in this article comprise the size of transaction costs, the level of confidence in the future exchange rate, the degree of correlation of business cycles, labour mobility, and nominal exchange rate volatility.

Undoubtedly, trade integration is the leading indicator presented by the literature as the one affected differently by mentioned regimes. Past research also identifies several bilateral trade indicators: BCS, financial integration, the probability of asymmetric shocks. Based on these findings, I developed my index, comprised of bilateral trade indicators and their determinants, which are affected differently by a CU and fixed rates. The sample included the CFA Franc Zone, the Eastern Caribbean Currency Union, and several dollarised countries. The second part of the article was devoted to these issues.

Considering all of the above, the index was constructed from the following variables: trade openness, trading partners trade importance, a correlation coefficient of detrended GDP, inflation similarities, and similarities of government debt and lending. Econometric research shows that the difference in trade integration for the samples follows factors other than the existence of a currency union. The currency union dummy appears to be significant in all models, regardless of the dependent variable. However, the coefficient of this dummy in some cases (American countries) appears to be negative. This indicates that we cannot reach a single conclusion about the difference in the influence on economic integration of a fixed exchange rate regime versus a currency union. Because the estimation outcome differs across each region, the proper analysis should be done for each specific case. Unfortunately, we cannot conduct the same research with a different sample because there is no other. To enrich this study and - possibly - obtain a less puzzling result, I propose the addition of other independent variables. For instance, by dividing trade into intra- and inter-industry trade. The inclusion of new dummy variables such as whether a country is landlocked or an oil exporter, along with the division of the categorical variable for cultural similarity into four separate dummies, may provide further insights. It is also worth trying to proxy physical distances between countries with physical distances between their capitals. Future research might also consider the inclusion of other economic variables proposed by integration indices, such as foreign direct investment flows or migration (Makieła et al., 2021).

Noteworthy, the results from these models should be interpreted with caution because some models exhibit heteroscedasticity, autocorrelation, or both. There is a possibility that robust standard errors - used to interpret the results - are not so precise as non-robust conventional ones.

\section{REFERENCES}

Adams, P. (2005). Theory and evidence for an African single currency. University of Manchester. Retrieved from https://ukdataservice.ac.uk/media/263205/adams-paper.pdf on December 3, 2019.

Afonso, A., Arghyrou, M., \& Kontonikas, A. (2015). The Determinants of Sovereign Bond Yield Spreads in the EMU. ECB Working Paper No. 1781. https://doi.org/10.2866/897469

Alesina, A., Barro, R., \& Tenreyro, S. (2002). Optimal Currency Areas. SSRN Electronic Journal. https://doi.org/10.2139/ssrn.319761

Androniceanu, A. (2020). Major structural changes in the EU policies due to the problems and risks caused by COVID-19. Administratie si Management Public, 34, 137-149. https://doi.org/10.24818/amp/2020.34-08

Androniceanu, A., Kinnunen, J., \& Georgescu, I. (2020). E-Government clusters in the EU based on the Gaussian Mixture Models. Administratie si Management Public, 35, 6-20. https://doi.org/10.24818/amp/2020.35-01. 
Backus, D.K., Kehoe, P.J., \& Kydland, F.E. (1992). International real business cycles. The Journal of Political Economy, 100(4), 745-775.

Bakucs, Z., Benedek, Z., \& Ferto, I. (2019). Spatial price transmission and trade in the european dairy sector. Agris on-Line Papers in Economics and Informatics, 11(2), 13-20. https://doi.org/10.7160/AOL.2019.110202

Baele, L., Ferrando, A., Hördahl, P., Krylova, E., \& Monnet, C. (2004). Measuring financial integration in the Euro Area. ECB Occasional Paper No 14.

Beck, K. (2013). Determinants of Business Cycles Synchronization in the European Union and the Euro Area. Equilibrium. Quarterly Journal of Economics and Economic Policy, 8(4), 25-48. https://doi.org/10.12775/EQUIL.2013.025

Beck, K. (2017). Bayesian Model Averaging and jointness Measures: Theoretical Framework and Application to the Gravity Model of Trade. Statistics in Transition New Series, 18(3), 393-412. https://doi.org/10.21307/stattrans-2016-077

Beck, K. (2019). What drives business cycle synchronization? BMA results from the European Union. Baltic Journal of Economics, 19(2), 248-275. https://doi.org/10.1080/1406099X.2019.1652393

Beck, T. (2003). Financial Dependence and International Trade. Review of International Economics, 11(2), $296-$ 316. https://doi.org/10.1111/1467-9396.00384

Beck, K., \& Janus. J. (2013). Aggregate Demand Disturbances in the Visegrad Group and the Eurozone. Entrepreneurial Business and Economics Review, 1(3), 7-20. https://doi.org/10.15678/EBER.2013.010302

Beck, K., \& Janus. J. (2014). Synchronization of Economic Shocks in The Visegrad Group: An Empirical Assessment. Studia Ubb Negotia, 2, 35-56.

Broda, C., \& Romalis, J. (2013). Identifying the Relationship between Trade and Exchange Rate Volatility. Commodity Prices and Markets, 20, https://doi.org/10.7208/chicago/9780226386904.003.0004

CEPII. Gravity. Retrieved from http://www.cepii.fr/CEPII/en/bdd_modele/presentation.asp?id=8 on November 2, 2019.

Corden, W. (1973). The adjustment problem. In L. Krause \& W. Salant (Eds.), European Monetary Unification and its Meaning for the United States. Washington, DC: Brookings.

Dautović, E., Orszaghova, L., \& Schudel, W. (2017). Converging in divergent ways: Explaining intra-industry trade between CESEE countries and the EU-15. Economics of Transition, 25, 625-662. https://doi.org/10.1111/ecot.12132

De Grauwe, P. (2012). Economics of currency union. Oxford: Oxford University Press.

Dellas, H., \& Tavlas, G.S. (2009). An optimum-currency-area odyssey. Journal of International Money and Finance, 28(7), 1117-1137. Retrieved from http://www.sciencedirect.com/science/article/pii/S0261-5606(09)000576 on August 8, 2019.

Ferto, I. (2018). Global agri-food trade competitiveness: Gross versus value added exports. Agris on-Line Papers in Economics and Informatics, 10(4), 39-47. https://doi.org/10.7160/aol.2018.100404

Fleming, J. (1971). On Exchange Rate Unification. The Economic Journal, 81(323), 467. https://doi.org/10.2307/2229844

Frankel, J., \& Rose, A. (1998). The Endogeneity of the Optimum Currency Area Criteria. Economic Policy, 4, 487512. https://doi.org/10.3386/w5700

Glick, R., \& Rose, A. (2002). Does a currency union affect trade? The time-series evidence. European Economic Review, 46(6), 1125-1151. https://doi.org/10.3386/w8396

Gorodnichenko, Y. (2015). Fix the Hryvnia? Never Again!. Retrieved from https://voxukraine.org/en/fix-the-hryvnia-never-again/ on January 9, 2020.

Gryczka, M. (2020). Changing role of middle income economies in contemporary international trade: comparative analysis. International Entrepreneurship Review, 6(1), 93-107. https://doi.org/10.15678/IER.2020.0601.06

Hargreaves, D., \& McDermott, J. (1999). Issues relating to optimal currency areas: theory and implications for New Zealand. Reserve Bank of New Zealand. Retrieved from https://www.rbnz.govt.nz/-/media/ReserveBank/Files/Publications/Bulletins/1999/1999sep62-3hargreavesmcdermott.pdf on August 8, 2019.

Inklaar, R., Jong-A-Pin, R., \& de Haan, J. (2008). Trade and Business Cycle Synchronization in OECD Countries: A Reexamination. European Economic Review, 52(4), 646-666. 
Imbs, J. (2004). Trade, finance, specialization, and synchronization. Review of Economics and Statistics, 86(3), 723-734.

Imbs, J. (2006). The real effects of financial integration. Journal of International Economics, 68(2), 296-324.

International Monetary Fund. (2004). Classification of Exchange Rate Arrangements and Monetary Policy Frameworks. Retrieved from https://www.imf.org/external/np/mfd/er/2004/eng/0604.htm on November 9, 2019.

International Monetary Fund. n.d. Direction of trade statistics. Retrieved from http://data.imf.org/?sk=9D6028D4-F14A-464C-A2F2-59B2CD424B85 on January 8, 2020.

Kenen, P. (1969). Theory of Optimum Currency Areas: An Eclectic View. In R. Mundell \& A. Swoboda (Eds.), Monetary Problems of the International Economy. Chicago: University of Chicago Press.

Klein, M., \& Shambaugh, J. (2004). Fixed exchange rate and trade. Journal of International Economics, 70(2), 359383. https://doi.org/10.1016/j.jinteco.2006.01.001

Klein, M., \& Shambaugh, J. (2006). Exchange rate regimes in the modern era. The MIT Press. https://doi.org/ $10.7551 /$ mitpress/9780262013659.003.0001

Kletzer, K., \& Bardhan, P. (1987). Credit markets and patterns of international trade. Journal of Development Economics, 27(1-2), 57-70. https://doi.org/ 10.1016/0304-3878(87)90006-x

Kinnunen, J., Androniceanu, A., \& Georgescu, I. (2019). The role of economic and political features in classification of countries in transition by Human Development Index. Informatica Economică, 23(4), 26-40.

König, J., \& Ohr, R. (2013). Different efforts in European economic integration: Implications of the EU index. JCMS. Journal of Common Market Studies, 51(6), 1074-1090. https://doi.org/10.1111/jcms.12058

Kose, M.A., Otrok, C., \& Prasad, E. (2012). Global business cycles: Convergence or decoupling?. International Economic Review, 53(2), 511-538. https://doi.org/10.1111/j.1468-2354.2012.00690.x

Kostiukevych, R., Mishchuk, H., Zhidebekkyzy, A., Nakonieczny, J., \& Akimov, O. (2020). The impact of European integration processes on the investment potential and institutional maturity of rural communities. Economics and Sociology, 13(3), 46-63. https://doi.org/10.14254/2071-789X.2020/13-3/3

Krugman, P. (1993). What do we need to know about the international monetary system?. Princeton University. Retrieved from https://ies.princeton.edu/pdf/E190.pdf on August 5, 2019.

Lane, P. (2006). The real effects of European currency union. The Journal of Economic Perspectives, 20(4), 47-66. https://doi.org/10.1257/jep.20.4.47

Loganathan, S., Karakunnel, J.J., \& Victor, V. (2020). Analysis of India's trade patterns and trade possibilities with the European Union. Forum Scientiae Oeconomia, 8(4), 5-25. https://doi.org/10.23762/FSO_VOL8_NO4_1

Maciejewski, M., \& Wach, K. (2019). What determines export structure in the EU countries? The use of gravity model in international trade based on the panel data for the years 1995-2015. Journal of International Studies, 12(1), 151-167. https://doi.org/10.14254/2071-8330.2019/12-1/10

Magnifico, G. (1971). European Monetary Unification for Balanced Growth: A New Approach. Princeton: Princeton University Press.

Makieła, K., Wojciechowski, L., \& Wach, K. (2021). Effectiveness of FDI, technological gap and sectoral level productivity in the Visegrad Group. Technological and Economic Development of Economy, 27(1), 149-174. https://doi.org/10.3846/tede.2020.14017

Malefane, M.R. (2021). Export-led growth hypothesis: empirical evidence from the Southern African Customs Union countries. Entrepreneurial Business and Economics Review, 9(2), 55-69. https://doi.org/10.15678/EBER.2021.090204

Martyniuk, V., \& Muravska, Y. (2020). Forming a foreign trade partnership strategy in the context of strengthening national economic security: A case study of Ukraine. Forum Scientiae Oeconomia, 8(2), 5-24. https://doi.org/10.23762/FSO_VOL8_NO2_1

McCallum, J. (1995). National borders matter: Canada-US regional trade patterns. The American Economic Review, 85(3), 615-623. Retrieved from http://www.jstor.org/stable/2118191 on January 8, 2020.

McKinnon, R.I. (1963). Optimum Currency Areas. The American Economic Review, 53(4), 717-25. Retrieved from http://www.jstor.org/stable/1811021 on January 8, 2020.

Mélitz, J. (1991). Brussels on a Single Money. Open Economies Review, 2(3), 323-336. https://doi.org/10.1007/bf01886150 
Mélitz, J. (2004). Risk Sharing and EMU. Journal of Common Market Studies, 42(4), 815-40. https://doi.org/10.1111/j.0021-9886.2004.00531.x

Mendizabal, H.R. (2002). Currency union and the transaction cost. Savings of a Single Currency. Review of International Economics, 10(2), 263-277. https://doi.org/10.1111/1467-9396.00331

Mishchuk, H., Samoliuk, N., Bilan, Y., Streimikiene, D. (2018). Income inequality and its consequences within the framework of social justice. Problemy Ekorozwoju, 13(2), 131-138.

Monnet, E., \& Puy, D. (2016). Has globalization really increased business cycle synchronization?. IMF Working Paper, 54.

Moździerz, A. (2019). Macroeconomic stability as the condition for Bulgaria to join the euro area. Equilibrium. Quarterly Journal of Economics and Economic Policy, 14(2), 295-315. https://doi.org/10.24136/eq.2019.014

Mundell, R. (1961). A theory of optimum currency areas. American Economic Review, 51(5), 657-665. https://doi.org/10.4236/tel.2012.24073

Mundell, R. (1973). Uncommon Arguments for Common Currencies. The Economics of Common Currencies, 114-132.

Nicita, A. (2013). Exchange rates, international trade and trade policies. International Economics, 135-136(56), 47-61. https://doi.org/10.1016/j.inteco.2013.10.003

Pagano, M., \& von Thadden, E-L. (2004). The European Bond Markets under EMU. Oxford Review of Economic Policy, 20(4), 531-554. Retrieved from https://ssrn.com/abstract=667922 on September 3, 2019.

Persson, T. (2001). Currency Union and trade. How large the treatment effect. Stockholm University. Retrieved from http://perseus.iies.su.se/ tpers/papers/010529b.pdf on August 3, 2019.

Ravn, M., \& Uhlig, H. (2002). On adjusting the Hodrick-Prescott filter for the frequency of observations. The Review of Economics and Statistics, 84(2), 371. https://doi.org/10.1162/003465302317411604

Reinhart, C., \& Rogoff, K. (2004). The modern history of exchange rate arrangements: a reinterpretation. Quarterly Journal of Economics, 119(1), 1-48. https://doi.org/10.3386/w8963

Rose, A. (2001). Currency unions and trade: The effect is large. Economic Policy, 16(33), 449-461. https://doi.org/10.1111/1468-0327.00082

Rose, A., \& Engel, C. (2002). Currency Unions and International Integration. Journal of Money, Credit and Banking, 34(4), 1067-1089. https://doi.org/10.1353/mcb.2002.0058

Skare, M., \& Porada-Rochoń, M. (2019a). Tracking financial cycles in ten transitional economies 2005?2018 using singular spectrum analysis (SSA) techniques. Equilibrium. Quarterly Journal of Economics and Economic Policy, 14(1), 7-29. https://doi.org/10.24136/eq.2019.001

Skare, M., \& Porada-Rochoń, M. (2019b). Financial and economic development link in transitional economies: a spectral Granger causality analysis 1991-2017. Oeconomia Copernicana, 10(1), 7-35. https://doi.org/10.24136/oc.2019.001.

Sriyana, J. (2019). Price stabilization policy in an emerging economy: An asymmetric approach. Journal of International Studies, 12(2), 165-181. https://doi.org/10.14254/2071-8330.2019/12-2/10

Smutka, L., Svatoš, M., Tomšík, K., \& Sergienko, O. I. (2016). Foreign trade in agricultural products in the Czech republic. Agricultural Economics (Czech), 62(1), 9-25. https://doi.org/10.17221/18/2015-AGRICECON

Stoykova, O. (2018). Optimum Currency Areas: theory and applications. Myśl Ekonomiczna i Polityczna, 4(63), 17-53. https://doi.org/10.26399/meip.4(63).2018.43/o.stoykova

Tenreyro, S. (2007). On the trade impact of nominal exchange rate volatility. Journal of Development Economics, 82(2), 485-508. https://doi.org/10.1016/j.jdeveco.2006.03.007

Thursby, J., \& Thursby, M. (1987). Bilateral trade flows, the linder hypothesis, and exchange risk. The Review of Economics and Statistics, 69(3), 488-495. https://doi.org/ 10.2307/1925537

World Bank. (2000). World development indicators. Retrieved from http://data.worldbank.org/data-catalog/world-development-indicators on August 9, 2020. 


\section{Appendix A: Justification of sample choice}

1. Choose two currency unions ( $A$ and $B$ ) that satisfy all conditions depicted in Figure 1.

2. Check integration within $C U A$ and within set of countries $B$.

3. Check integration between currency union $A$ and set of countries $B$.

4. If integration in point 2 is higher than integration in point 3 , conclude that currency union results in greater economic integration then fixed exchange rate regime.

5. Run a regression on integration with $\mathrm{CU}$ dummy as the independent variable to ensure that the difference in integration is caused by currency union and not other factors.

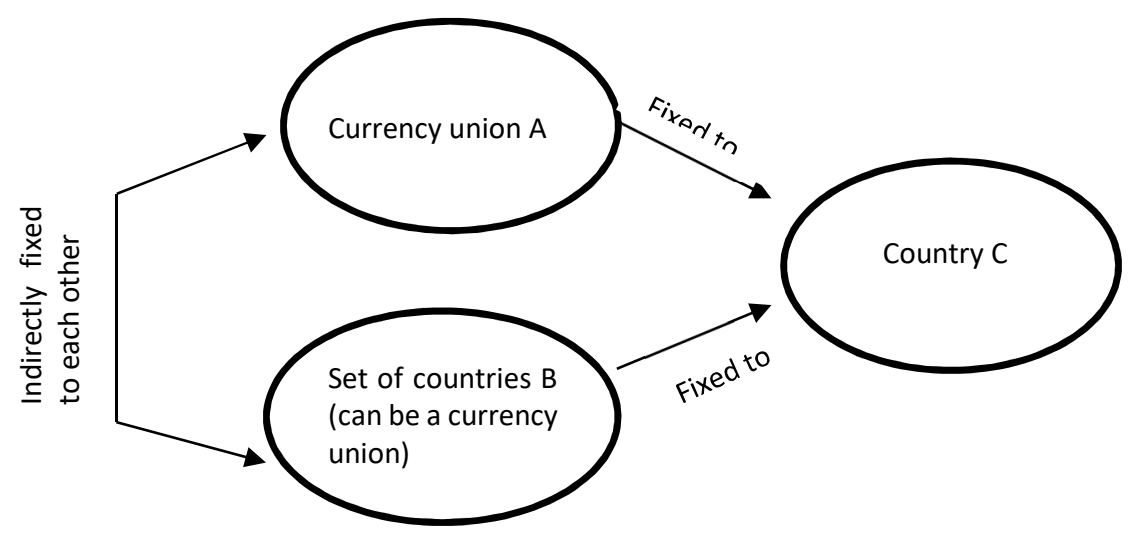

Figure A.1. Conditions for countries to fit required samples Source: own elaboration.

\section{Appendix B: Weighting procedure}

PCA aims to reduce the dimension of the data set by creating new variables, which are called principal components, while keeping the highest possible number of variations. All new variables created by PCA are orthogonal. Mathematically, the procedure can be expressed in the following way:

Firstly, PCA looks for the $a_{1}^{\prime} x$, which is the linear function of the element of a random vector $x$ with the maximum variance.

where:

$$
a_{1}^{\prime} x=a_{11} x_{1}+a_{12} x_{2}+\cdots+a_{1 n} x_{n}=(x+a)^{n}=\sum_{j=1}^{n} a_{1 j} x_{j}
$$

$x_{1}, x_{2}, x_{n}-=$ the corresponding element of a random vector $\mathrm{x}$ with $\mathrm{n}$ dimensions;

$a_{1}^{\prime} x-=$ first principal component.

Secondly, the procedure finds $a_{2}^{\prime} x$, which is uncorrelated with $a_{1}^{\prime} x$. This is continuous until $a_{k}^{\prime} x$, being uncorrelated with $a_{1}^{\prime} x, a_{2}^{\prime} x \ldots a_{k-1}^{\prime} x$. The maximum possible number of principal components equals the length of the vector $x$. However, it is generally believed that all variation of $x$ will be presented by the $p$ principal component, where $p$ is much less than n. Figures B.1 and B.2 depict the distribution of 50 observations for the vector $\mathrm{x}$ with $\mathrm{n}=2$ prior and after PCA. 


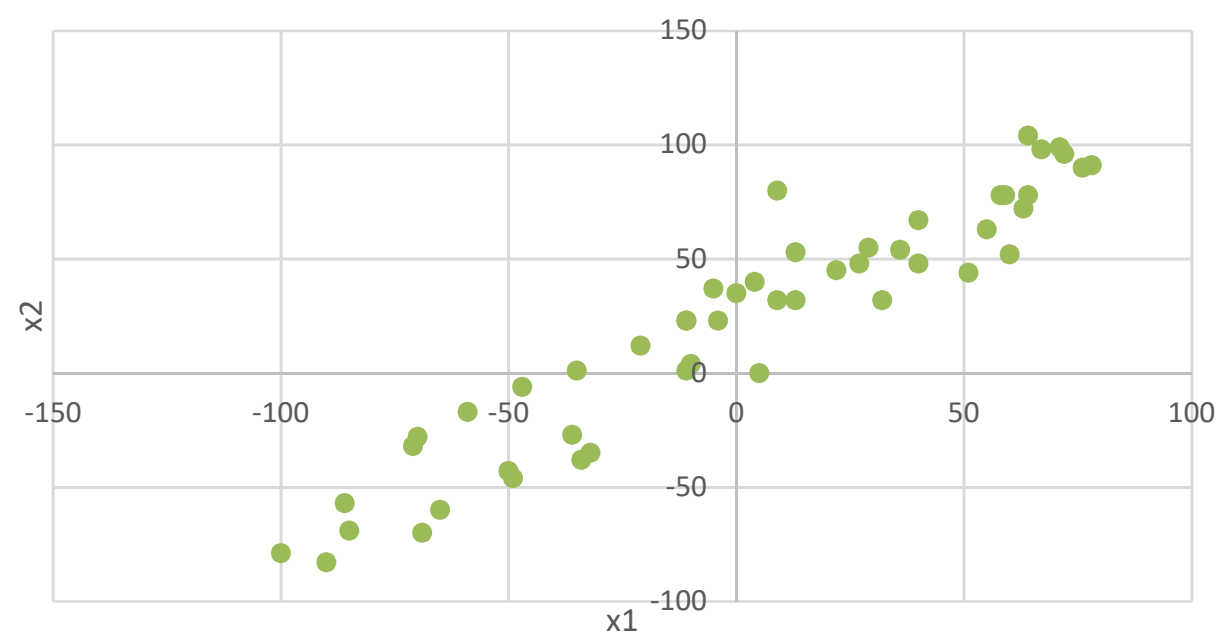

Figure B.1. 50 observations before PCA analysis Source: own elaboration.

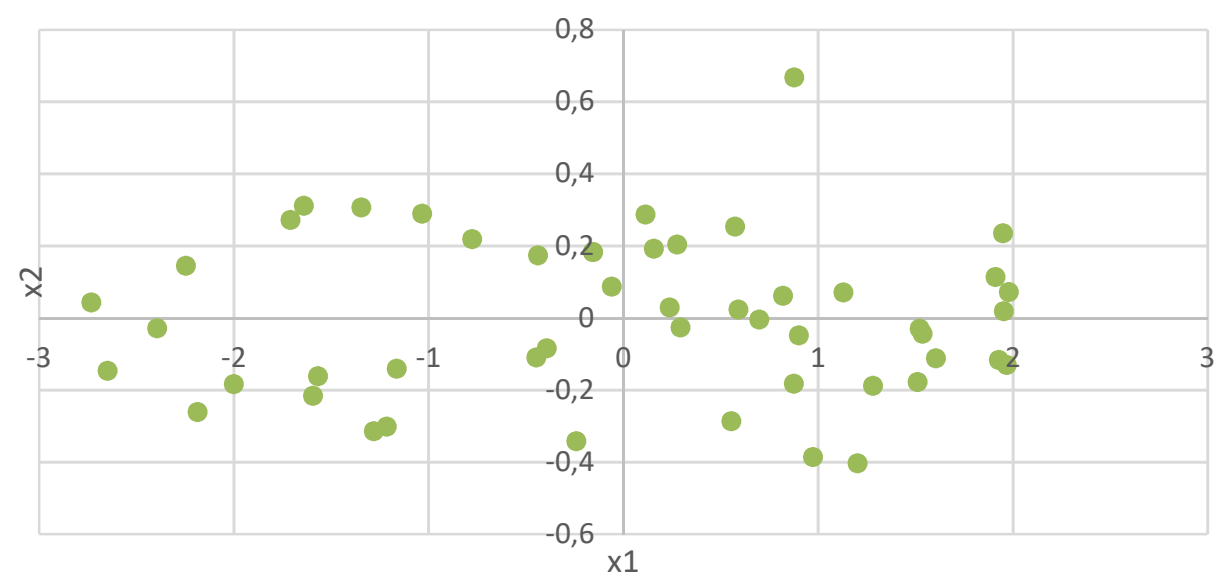

Figure B.2. 50 observations after PCA analysis Source: own elaboration. 


\section{Appendix C: Results for the index}

Table C.1. The index for African countries

\begin{tabular}{|c|c|c|c|c|c|c|c|c|c|c|c|c|c|}
\hline Country Code* & BJ & BF & CM & CF & TD & CG & GQ & GA & GW & ML & NE & SN & TG \\
\hline BJ & $\mathrm{x}$ & 0.154 & -0.023 & . & -0.018 & 0.052 & 0.079 & 0.003 & . & 0.016 & 0.234 & 0.141 & 0.372 \\
\hline $\mathrm{BF}$ & 0.154 & $x$ & -0.14 & . & . &. & . &. & . & 0.198 & 0.131 & 0.15 & 0.15 \\
\hline $\mathrm{CM}$ & . &. & $\mathrm{X}$ & 0.053 & 0.165 & 0.267 & 0.129 & 0.162 & . & . & . &. & . \\
\hline CF & . & . & 0.409 & $\mathrm{X}$ & 0.149 &. & 0.041 &. & . & . & . & . & . \\
\hline TD & . & . & 0.241 & 0.099 & $\mathrm{X}$ & 0.208 & . & 0.162 & . & . & . & . & . \\
\hline CG & . & . & 0.405 & 0.02 & 0.243 & $\mathrm{X}$ & 0.265 &. & . & . & . & . & . \\
\hline $\mathrm{GQ}$ & . & . & 0.201 &. &. & 0.371 & $\mathrm{X}$ & 0.13 & . & . & . & . & . \\
\hline GA & . & . & 0.226 & 0.03 & 0.134 & 0.225 & 0.145 & $x$ & . & . & . & . & . \\
\hline GW &. & . &. & . & . & . & . &. & $x$ &. & . & . & 0.202 \\
\hline $\mathrm{ML}$ & 0.214 & 0.195 & 0.065 & -0.07 & . & 0.06 & 0.042 & 0.017 &. & $x$ &. &. & 0.175 \\
\hline $\mathrm{NE}$ & 0.277 & 0.144 & 0.061 & . & 0.085 &. & . & 0.002 & . & 0.257 & $X$ & 0.145 & 0.248 \\
\hline SN & . & 0.205 & -0.083 & . & . & 0.002 & -0.013 & -0.044 &. & 0.274 & 0.11 & $x$ & 0.093 \\
\hline TG & 0.333 & . & 0.095 & . & . & 0.086 & 0.092 & 0.013 & 0.139 & 0.262 & 0.315 & 0.143 & $X$ \\
\hline
\end{tabular}

* Legend to Alpha 2 - country codes: BJ-Benin, BF-Burkina Faso, CM - Cameroon, CF-Central African Republic, TD-Chad, Congo-CG, Equatorial Guinea - GQ, Gabon - GA, Guinea-Bissau - GW, Mali-ML, Niger - NE, Senegal - SN, Togo-TG Source: own study.

Table C.2. The index for American countries

\begin{tabular}{|c|c|c|c|c|c|c|c|c|c|c|c|c|}
\hline Country Code* & AG & AW & BS & BB & BZ & DM & GD & PA & KN & LC & VC & VE \\
\hline$A G$ & $\mathrm{X}$ & 0.183 & 0.288 & 0.536 & 0.279 & 0.343 & 0.321 & 0.397 & 0.317 & 0.288 & 0.394 & 0.269 \\
\hline AW &. & $\mathrm{X}$ & 0.221 & 0.228 & 0.19 &. & . & 0.194 & . & & & 0.203 \\
\hline BS & . & 0.174 & $x$ & 0.191 & 0.119 & . & . & 0.193 & . & . & . & 0.154 \\
\hline BB & . & 0.154 & 0.152 & $x$ & 0.142 & . & . & 0.161 & . & . & . & 0.095 \\
\hline $\mathrm{BZ}$ & . &. & 0.1 & 0.115 & $x$ & & & 0.089 &. &. &. &. \\
\hline $\mathrm{DM}$ & 0.103 & 0.103 & 0.116 & 0.073 & 0.084 & $x$ & 0.086 & 0.166 & 0.12 & 0.072 & 0.122 &. \\
\hline GD & 0.03 &. & 0.028 & 0.049 &. & 0.039 & $X$ &. & 0.029 & 0.088 & 0.077 & 0.031 \\
\hline $\mathrm{PA}$ &. & . & 0.059 &. & 0.013 &. & . & $\mathrm{X}$ &. &. &. & 0.063 \\
\hline $\mathrm{KN}$ & 0.11 & . & 0.004 & 0.023 & 0.029 & 0.019 & 0.06 & 0.046 & $x$ & 0.004 & 0.028 & 0.075 \\
\hline LC & 0.011 & . & 0.032 & 0.043 &. & 0.02 & 0.046 & 0.025 &. & $x$ & 0.06 &. \\
\hline VC & 0.011 & 0.046 & 0.004 & 0.008 & 0.027 & 0.062 & 0.001 & & -0.009 & 0.008 & $x$ & 0.004 \\
\hline VE & . & 0.023 & & 0.04 & & & & 0.031 & & & & $x$ \\
\hline
\end{tabular}

* Legend to Alpha 2 - country codes: Antigua and Barbuda - AG, Aruba - AW, Bahamas - BS, Barbados - BB, Belize - BZ, Dominica DM, Grenada - GD, Panama -PA Saint Kitts and Nevis -KN, Saint Lucia -LC, Saint Vincent and The Grenadines -VC, Venezuela-VE Source: own study. 


\section{Appendix D: Quantile regression models}

Table D.1. Estimation results for African countries, quantile regression model

\begin{tabular}{|l|l|l|l|}
\hline \multicolumn{1}{|c|}{ Dependent Variable } & \multicolumn{1}{c|}{ Index } & Trading Partner Trade Importance & Trade Openness \\
\hline Independent variables & $\mathrm{X}$ & $\mathrm{X}$ & $\mathrm{X}$ \\
\hline Constant term & $0.399442^{* *}$ & 0.01000 & 0.004211 \\
\hline Log of physical distance & $-0.04882^{*}$ & -0.00162 & -0.00063 \\
\hline Currency union dummy & $0.110361^{* * *}$ & $0.005436^{* *}$ & $0.00421^{* *}$ \\
\hline Categorical variable "similarities" & -0.00307 & 0.00100 & 0.002154 \\
\hline Pseudo R-squared & 0.32241 & 0.15805 & 0.12082 \\
\hline Adj. R-squared & 0.29457 & 0.12345 & 0.08468 \\
\hline
\end{tabular}

*** significance at the $1 \%$ level, ${ }^{* *}$ significance at the $5 \%$ level, ${ }^{*}$ significance at the $10 \%$ level

Source: own study.

Table D.2. Estimation results for American countries, quantile regression model

\begin{tabular}{|l|l|l|l|}
\hline Dependent Variable & Index & Trading Partner Trade Importance & Trade Openness \\
\hline Independent variables & $\mathrm{X}$ & $\mathrm{X}$ & $\mathrm{X}$ \\
\hline Constant term & $2.126249^{* * *}$ & $0.033696^{* * *}$ & $3.934849^{* * *}$ \\
\hline Log of physical distance & $-0.367575^{* * *}$ & $-0.00162^{* * *}$ & $-0.531757^{* * *}$ \\
\hline Currency union dummy & $-0.369762^{*}$ & $-0.005016^{*}$ & $-0.534923^{*}$ \\
\hline Categorical variable "similarities" & $0.092186^{*}$ & 0.000770 & 0.126137 \\
\hline Pseudo R-squared & 0.16419 & 0.180392 & 0.16419 \\
\hline Adj. R-squared & 0.13163 & 0.14846 & 0.13163 \\
\hline
\end{tabular}

*** significance at the $1 \%$ level, ${ }^{* *}$ significance at the $5 \%$ level, ${ }^{*}$ significance at the $10 \%$ level

Source: own study.

\section{Appendix E: Strategy from general to specific}

Table E.1. Estimation results for American countries, strategy from general to specific

\begin{tabular}{|l|l|l|l|}
\hline Dependent Variable & Index & Trading Partner Trade Importance & Trade Openness \\
\hline Independent variables & $\mathrm{X}$ & $\mathrm{X}$ & $\mathrm{X}$ \\
\hline Constant term & $0.362821^{* * *}$ & $0.058593^{* * *}$ & $0.252991^{* *}$ \\
\hline Log of physical distance & $-0.044796^{* *}$ & $-0.007691^{* * *}$ & $-0.033229^{* *}$ \\
\hline Currency union dummy & $0.139257^{* * *}$ & $0.008530^{* *}$ & $0.031594^{* * *}$ \\
\hline Categorical variable "similarities" & $\begin{array}{l}\text { Dropped due to in- } \\
\text { significance }\end{array}$ & Dropped due to insignificance & $\begin{array}{l}\text { Dropped due to } \\
\text { insignificance }\end{array}$ \\
\hline R-squared & 0.52428 & 0.23632 & 0.22681 \\
\hline Adj. R-squared & 0.51143 & 0.21568 & 0.20591 \\
\hline
\end{tabular}

*** significance at the $1 \%$ level, ${ }^{* *}$ significance at the $5 \%$ level, $*$ significance at the $10 \%$ level

Source: own study. 


\section{Author}

\section{Oleksandra Stoykova}

Bachelor of Business Economics (Lazarski University, Poland); Master in Economics (Warsaw School of Economics, Poland). Her research interests include International Economics, Macroeconomics and Empirical Economics. Correspondence to: Mgr Oleksandra Stoykova, Lazarski University, Faculty of Economics and Management, ul. Świeradowska 43, 02-662 Warsaw, Poland, e-mail: oleksandrastoykova@gmail.com ORCID ๑i http://orcid.org/0000-0001-5951-8400

\section{Conflict of Interest}

The Author declares that the research was conducted in the absence of any commercial or financial relationships that could be construed as a potential conflict of interest.

\section{Copyright and License}

This article is published under the terms of the Creative Commons

Attribution - NoDerivs (CC BY-ND 4.0) License

http://creativecommons.org/licenses/by-nd/4.0/

Published by Cracow University of Economics - Krakow, Poland 